\title{
Methanol as the Hydrogen Source in the Selective Transfer Hydrogenation of Alkynes Enabled by a Manganese Pincer Complex
}

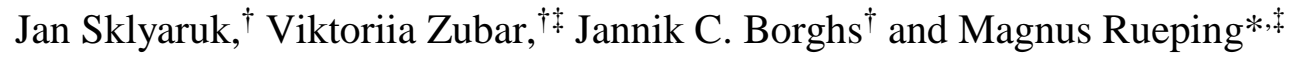 \\ Institute of Organic Chemistry, RWTH Aachen University, Landoltweg 1, 52074 Aachen, Germany \\ *KAUST Catalysis Center (KCC), King Abdullah University of Science and Technology (KAUST), Thuwal 23955-6900, \\ Saudi Arabia
}

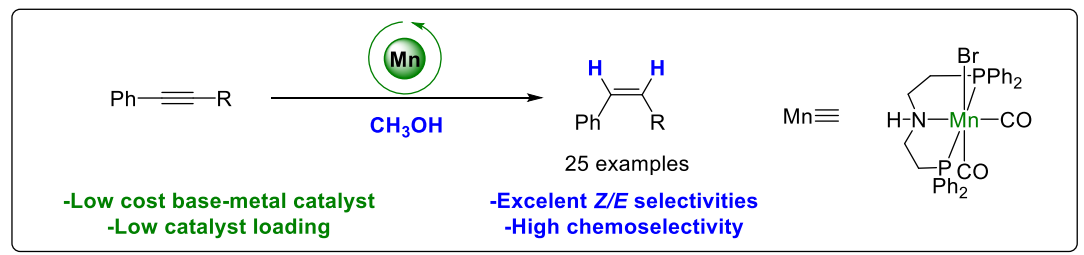

\begin{abstract}
The first base metal catalyzed transfer hydrogenation of alkynes with methanol is described. An air and moisture stable manganese pincer complex catalyzes the reduction of a variety of different alkynes to the corresponding $(Z)$-olefins in high yields. The reaction is stereo- and chemoselective and scalable.
\end{abstract}

Olefins play an important role among bioactive molecules, pharmaceuticals, polymers and functional materials. ${ }^{1,2}$ Furthermore, olefins can be functionalized into a vast variety of different compounds. ${ }^{3}$ A common method for the synthesis of $(Z)$-olefins is the semi-hydrogenation of alkynes using the Pdbased Lindlar catalyst and hydrogen gas (Scheme 1A). ${ }^{4}$ Besides, several cis-selective hydrogenation methods have been developed which mainly rely on the use of noble metals. ${ }^{5}$ In order to avoid the use of pressurized hydrogen gas, transfer hydrogenation methods which apply hydrogen donors, such as ammonia formates, ${ }^{6 \mathrm{a}}$ formic acid, ${ }^{6 \mathrm{~b}-\mathrm{c}}$ silanes $^{6 \mathrm{~d}}$ and boranes, ${ }^{6 \mathrm{e}}$ evolved as alternatives. However, these methods may have disadvantages due to functional group tolerance, their relatively high prices and significant by-product formation (Scheme 1B). In this regard, alcohols, especially methanol, are highly desirable as hydrogen donors. ${ }^{7}$ Methanol is a very attractive hydrogen source, is produced on a large scale and is one of the most important $\mathrm{C}_{1}$ building blocks for the production of bulk and fine chemicals. The possibility to produce methanol from the greenhouse gas carbon dioxide highlights the sustainability of this hydrogen donor. In the proposed "methanol economy", methanol is considered as a promising hydrogen storage material, which can also be directly used as an alternative fuel for internal combustion and other engines, either in combination with gasoline or neat and in methanol fuel cells. ${ }^{8}$ In the case of methanol, the dehydrogenation step is more energy demanding than for other alcohols. ${ }^{9}$ Hence, it is challenging to develop catalysts, which are active for both the dehydrogenation step of methanol and the semi-hydrogenation of unsaturated triple bonds to selectively form $(Z)$-olefins. This research field is so far rather underdeveloped, and to the best of our knowledge, no general studies exist for the base metal catalyzed highly selective semi-hydrogenation of alkynes towards the formation of (Z)-olefins using methanol as hydrogen source.
Recently, the field of manganese pincer catalyzed (de-) hydrogenation reactions has received much attention. ${ }^{9,10}$ Various publications described the manganese complex catalyzed activation and synthetic utilization of methanol, whereby methanol was mainly applied as methylating reagent. ${ }^{11}$ However, recently reported manganese catalyzed hydrogen borrowing and transfer hydrogenation catalysis ${ }^{11,12}$ indicated that manganese pincer complexes may be suitable for the activation of methanol in the semi transfer hydrogenation of alkynes (Scheme 1C).

Scheme 1. Different Methods for the (Transfer)Hydrogenation of Alkynes

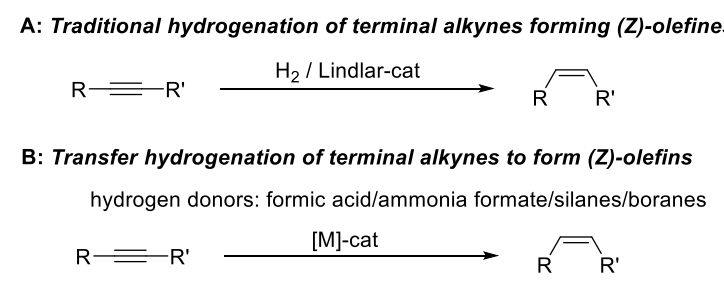

C: This work: (Z)-selective manganese catalyzed transfer hydrogenation

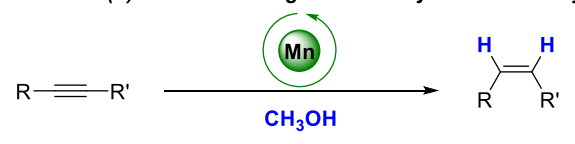

Thus, we evaluated different manganese complexes Mn-1 to Mn-5 as catalysts in the transfer hydrogenation of 1-methoxy4-(phenylethynyl) benzene (1a) (Table 1, entries 1-5). Surprisingly, complex Mn-1, which is known to be active in the alkylation of ketones and nitriles, gave a yield of $49 \%$, forming almost exclusively the corresponding $Z$-isomer 2a (Table 1, entry 1). 
On the other hand, the pyridyl-based complex Mn-2, previously used in the $\alpha$-methylation of ketones, ${ }^{11 \mathrm{i}}$ showed to be completely inactive in this transformation (Table 1, entry 2). To evaluate the importance of the phosphine moiety, we applied the aliphatic phosphine based complex $\mathbf{M n - 3}$ in the transformation. Although this complex is also known to be active in the alkylation of ketones, ${ }^{12 a}$ only trace amounts of product $\mathbf{2 a}$ were obtained (Table 1, entry 3).

Table 1. Optimization of the Reaction Conditions ${ }^{a}$

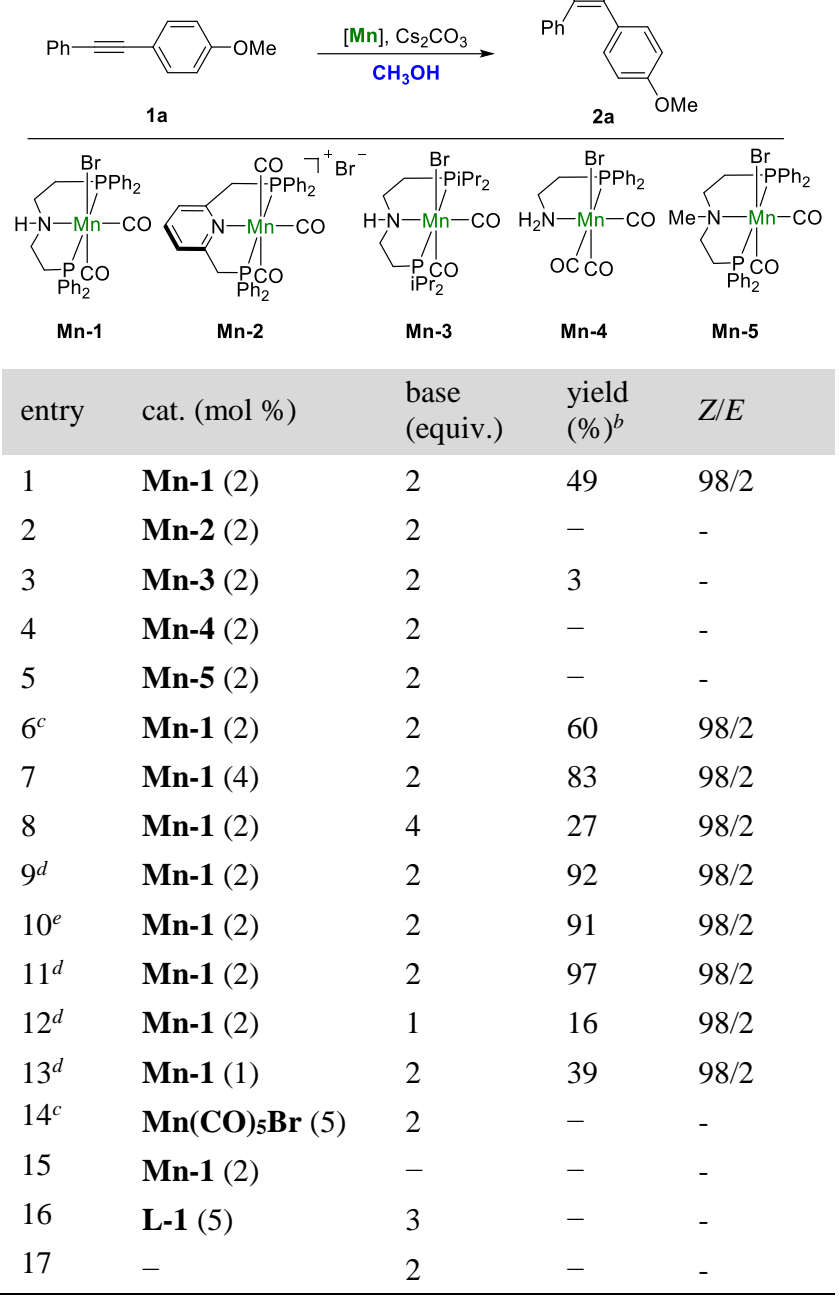

${ }^{a}$ Reaction conditions: $\mathbf{1 b}(0.1 \mathrm{mmol}),[\mathrm{Mn}], \mathrm{Cs}_{2} \mathrm{CO}_{3}$, methanol $(0.1$ $\mathrm{mL}), 14 \mathrm{~h}$, entries 1-10: $135^{\circ} \mathrm{C}$, entries $11-17: 150{ }^{\circ} \mathrm{C} .{ }^{b}$ Yields were determined by ${ }^{1} \mathrm{H}-\mathrm{NMR}$ spectroscopy using acetonitrile as internal standard. Heating inside an aluminum block. ${ }^{c}$ Methanol $(0.2 \mathrm{~mL})$. ${ }^{d}$ Toluene as cosolvent $(0.1 \mathrm{~mL}) .{ }^{e}$ Methanol $(0.2 \mathrm{~mL})$ and Toluene $(0.2 \mathrm{~mL})$

Also, the bidentate complex Mn-4, which is catalytically active in ester hydrogenation, ${ }^{13}$ was inactive in the transfer hydrogenation reaction (Table 1 , entry 4 ), highlighting the noninnocent behavior of the pincer backbone. Furthermore, N-Me based complex Mn-5 did not give any yield, illustrating the necessity of the NH-functionality (Table 1, entry 5). The catalyst screening emphasized the importance of the aliphatic pincer backbone and the significance of aromatic phosphines in the semi transfer hydrogenation of alkynes. Increasing the amount of methanol and the amount of catalyst improved the yield (Table 1, entries 6-7).
In contrast, the catalytic activity decreased for higher base loading (Table 1, entry 8). Moreover, the utilization of toluene as cosolvent increased the yield significantly (Table 1, entry 9), while decreasing the concentration of the reaction system did not improve the yield (Table 1, entry 10). More detailed base and cosolvent screening is summarized in the supporting information.

Scheme 2. Manganese Catalyzed Transfer Hydrogenation of Alkynes ${ }^{a}$

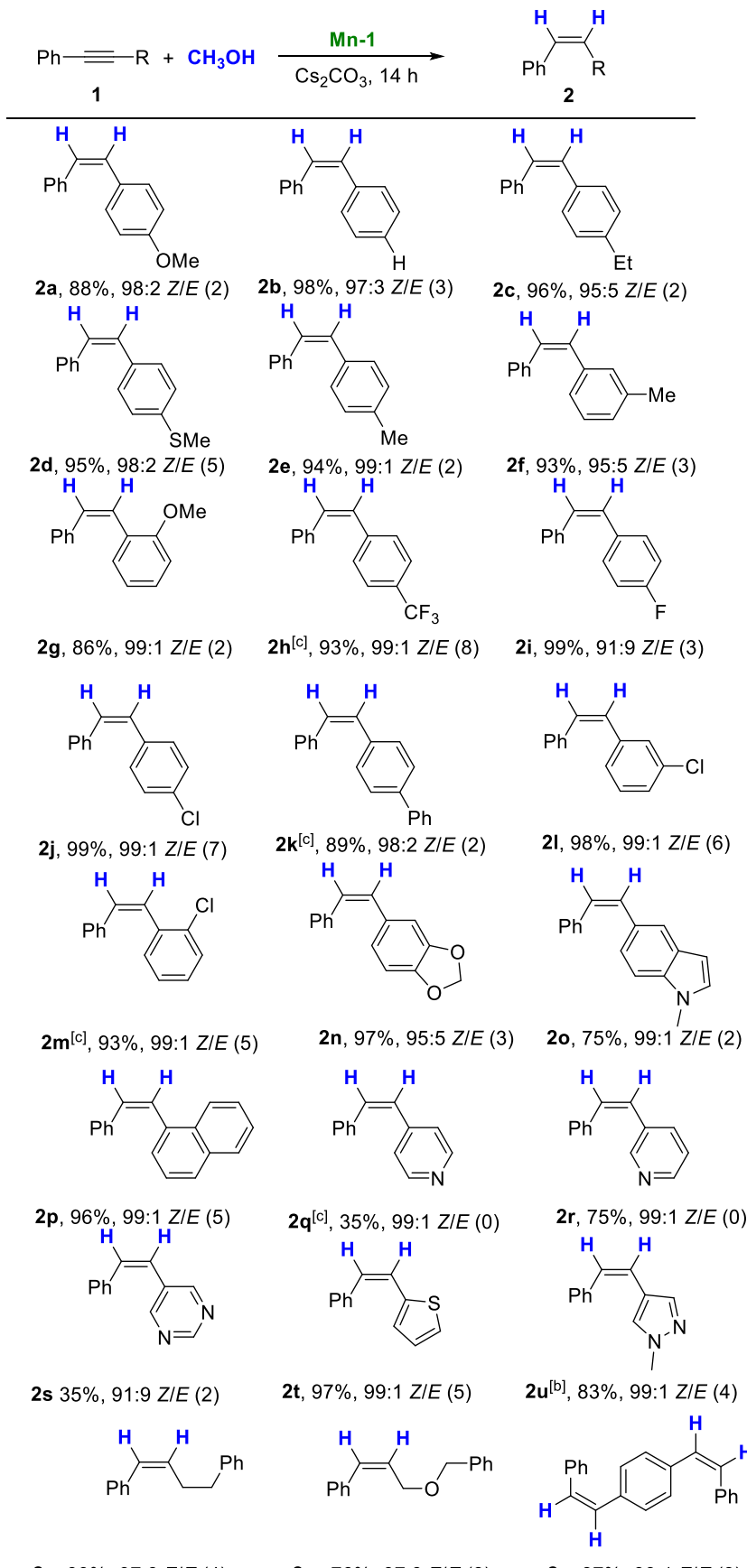

2v, 99\%, 97:3 ZIE (4) 2w, 76\%, 97:3 ZIE (8) 2x, 87\%, 99:1 ZIE (8) ${ }^{a}$ Reaction conditions: $1(0.3 \mathrm{mmol}), \mathrm{Cs}_{2} \mathrm{CO}_{3}(0.6 \mathrm{mmol}), \mathbf{M n}-1$ (2 $\mathrm{mol} \%)$ in $\mathrm{CH}_{3} \mathrm{OH}(0.3 \mathrm{~mL})$ and toluene $(0.3 \mathrm{~mL})$ at $150{ }^{\circ} \mathrm{C} .{ }^{b} 130$ ${ }^{\circ} \mathrm{C}$. ${ }^{c} \mathrm{Mn}-1$ (4 mol \%). Over hydrogenation product is presented in brackets. Heating inside an aluminum block. 
Increasing the reaction temperature provided an almost quantitative yield of $97 \%$ with ( $Z$ )-product 2a formed exclusively (Table 1 , entry 11). Control experiments proved the efficiency of the chosen catalytic system (Table 1, entries 1417). When other alcohols, such as ethanol and isopropanol were used as hydrogen sources, quantitative yields were also obtained (see SI). Additionally, no impact was observed when a drop of mercury was added to the reaction mixture, which suggests the homogeneous nature of the catalyst under these reaction conditions. ${ }^{14}$

After measuring the kinetic profile of the reaction (see SI), the reaction time was set to $14 \mathrm{~h}$. In the further course of the work we applied the optimized reaction conditions (Table 1, entry 11) in the transfer hydrogenation of various internal alkynes (Scheme 2). Unfortunately, terminal alkynes proved to be inactive in the transfer hydrogenation reaction.

Generally, the alkyne derivatives 1a-x were reduced to the corresponding olefins $\mathbf{2} \mathbf{a}-\mathbf{x}$ with high selectivity in moderate to quantitative yields. Stilbene $\mathbf{2 a}$ was isolated in a very good yield of $88 \%$ with a $Z / E$ ratio of $98: 2$. In the further course of the scope evaluation, both, electron donating (2b-g, 2n) and electron withdrawing substituents $(\mathbf{2} \mathbf{j}-\mathbf{m})$ were tolerated in ortho-, meta- and para-positions of the aromatic moiety of the alkynes. Various heterocycle containing alkynes (1o, 1q-u) were tolerated in the transformation. Also, the longer chained internal olefins $\mathbf{2 v}$ and $\mathbf{2 w}$ were isolated in high yields with good selectivity. It is important to note, that for substrates, such as $\mathbf{1 h}, \mathbf{1 j}, \mathbf{1 l}, \mathbf{1 w}$ and $\mathbf{1 x}$, some over hydrogenation into the corresponding diarylethanes was observed. To present the generality of the transformation, we applied our catalytic system in a gram scale synthesis of (Z)-stilbene (2b) (Scheme $3)$. The desired product $\mathbf{2 b}$ was obtained in quantitative yield with an excellent $Z / E$ ratio of $97: 3$. When $(Z)$ or $(E)$-stilbenes 2b were used, no isomerization or hydrogenation occurred. (see SI).

\section{Scheme 3. Gram-scale Synthesis of (Z)-Stilbene (2b) ${ }^{a}$}

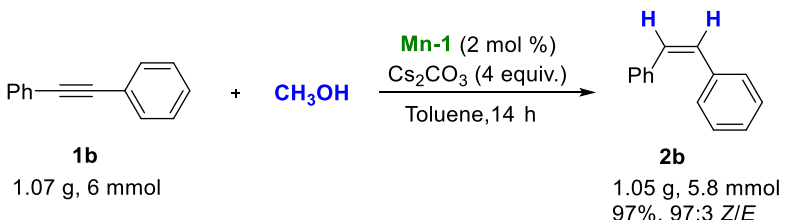

Next, we used fully deuterated methanol $\mathrm{CD}_{3} \mathrm{OD}$ to investigate the incorporation position of hydrogen (Scheme 4).

Scheme 4. Deuterium Labeling Using $\mathrm{CD}_{3} \mathrm{OD}$ in the Transfer Deuteration of Alkynes

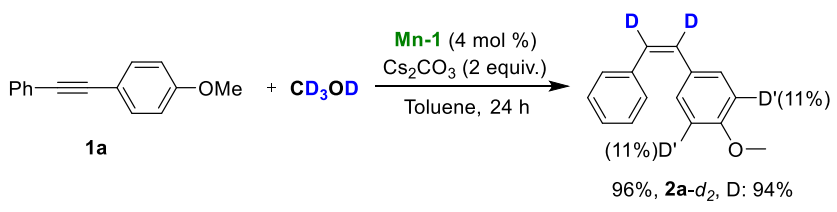

In the olefinic position, the value of deuterium incorporation reached $94 \%$ and this result indicates the possibility of cisselective deuterium incorporation. Due to the importance of deuterium labeled compounds, ${ }^{15}$ this transformation might be evaluated in further work (Scheme 4). Beyond that, we observed significant H/D-exchange in ortho position next to the methoxy group of $\mathbf{2 a}$.

Based on these observations we propose the following catalytic cycle (Scheme 5). In the first step the air and moisture stable precursor Mn-1 is activated by base to give the active species Mn-1a. Methanol coordinates to the active species Mn-1a, which is the deprotonated via metal ligand interactions, forming the manganese methoxide complex Mn-1b. ${ }^{12 \mathrm{~d}}$ The following deprotonation of the methoxide moiety results in formaldehyde elimination, so that the hydride species Mn-1c is obtained. Subsequent alkyne coordination and insertion into the manganese-hydride bond leads to the formation of Mn-1d. In the next step the elimination of (Z)-stilbene occurs, to regenerate the active Mn-1a catalyst. However, an alternative pathway starting from Mn-1d is conceivable in which methanol facilitates elimination of the $(Z)$-stilbene and directly provides the Mn-1b intermediate. Alternatively, Mn-1a can also be directly converted to Mn-1c via a six-membered transition state. $^{12 \mathrm{e}}$

Scheme 5. Proposed catalytic cycle for the manganese catalyzed transfer hydrogenation of alkynes with methanol

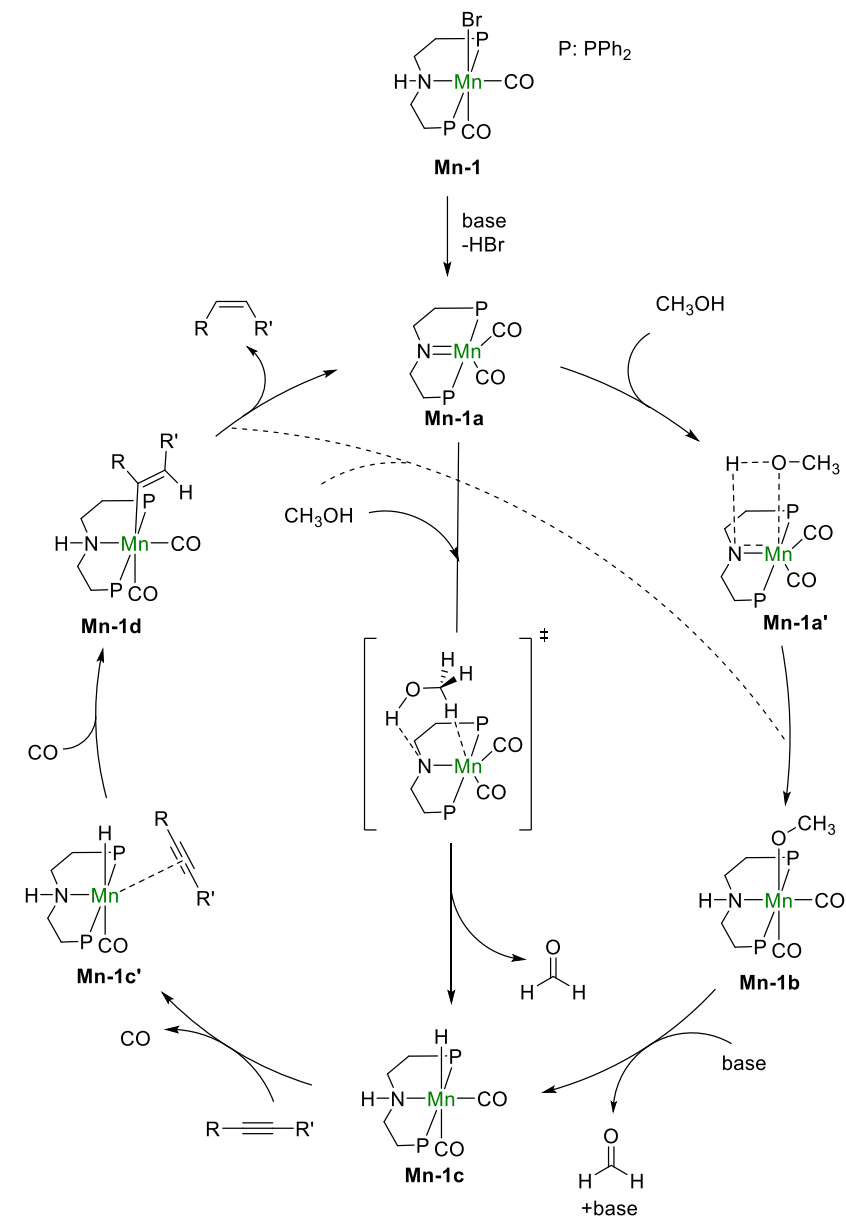

In conclusion, we developed the first base metal catalyzed semitransfer hydrogenation of alkynes, using methanol as a hydrogen donor. The applicability of this transformation was demonstrated for a variety of different alkynes, giving the corresponding $(Z)$-olefins in moderate to quantitative yields and high chemoselectivity. The reaction is scalable and deuterium labeling experiments demonstrate the cis-selective hydrogen incorporation. 


\section{ASSOCIATED CONTENT}

\section{Supporting Information}

The Supporting Information is available free of charge on the ACS Publications website.

Experimental procedures and characterization of compounds (file type, i.e., PDF)

\section{AUTHOR INFORMATION}

\section{Corresponding Author}

*Email: magnus.rueping@kaust.edu.sa

Notes

The authors declare no competing financial interest.

\section{ACKNOWLEDGMENT}

JS thanks the VCI (Verband der Chemischen Industrie) for the Chemiefonds-Stipendium. JCB would like to acknowledge the DBU (Deutsche Bundesstiftung Umwelt) for the doctoral fellowship. This work was financially supported by the King Abdullah University of Science and Technology (KAUST), Saudi Arabia, Office of Sponsored Research (FCC/1/1974).

\section{REFERENCES}

(1) (a) Cushman, M.; Nagarathnam, D.; Gopal, D.; Chakraborti, A. K.; Lin, C. M.; Hamel, E. J. Med. Chem. 1991, 34, 2579-2588. (b) Sackett, D. L. Pharmacol. Ther. 1993, 59, 163-228. (c) Ohsumi, K.; Nakagawa, R.; Fukuda, Y.; Hatanaka, T.; Morinaga, Y.; Nihei, Y.; Ohishi, K.; Suga, Y.; Akiyama, Y.; Tsuji, T. J. Med. Chem. 1998, 41, 3022-3032. (d) Tron, G. C.; Pirali, T.; Sorba, G.; Pagliai, F.; Busacca, S.; Genazzani, A. A. J. Med. Chem. 2006, 49, 3303-3044. (e) Baur, J. A.; Sinclair, D. A. Nat. Rev. Drug Discov. 2006, 5, 493-506.

(2) (a) Cameron, G. G.; Grassie, N. Macromol. Chem. Phys. 1961, 130-136. (b) Xu, J. F.; Chen, Y. Z.; Wu, D.; Wu, L. Z.; Tung, C. H.; Yang, Q. Z. Angew. Chem. Int. Ed. 2013, 52, 9738-9742. (c) Sakaguchi, T.; Yumoto, K.; Shiotsuki, M.; Sanda, F.; Yoshikawa, M.; Masuda, T. Macromolecules 2005, 38, 2704-2709. (d) Yamauchi, K.; Takashima, Y.; Hashidzume, A.; Yamaguchi, H.; Harada, A. J. Am. Chem. Soc. 2008, 130, 5024-5025. (e) Ikejiri, S.; Takashima, Y.; Osaki, M.; Yamaguchi, H.; Harada, A. J. Am. Chem. Soc. 2018, 40, 17308-17315.

(3) (a) Lane, B. S.; Burgess, K. Chem. Rev. 2003, 103, 2457-2473. (b) Yuan, Y. A.; Lu, D. F.; Chen, Y. R.; Xu, H. Angew. Chem. Int. Ed. 2016, 55, 534-538. (c) Chen, J.; Guo, J.; Lu, Z. Chin. J. Chem. 2018, $36,1075-1109$

(4) Lindlar, H. Helv. Chim. Acta 1952, 35, 446-450.

(5) (a) Schrock, R. R.; Osborn, J. A. J. Am. Chem. Soc. 1973, 98, 2143-2147. (b) Sharma, V. M.; Choudary, M.; Sarma, M. R.; Koteswara, K. J. Org. Chem. 1989, 54, 2997-2998. (c) van Laren, M. W.; Elsevier, C. J. Angew. Chem. Int. Ed. 1999, 111, 3715-3717. (d) Chernichenko, K.; Madarasz, A.; Papai, I.; Nieger, M.; Leskela, M.; Repo, T. Nat. Chem. 2013, 5, 718-723. (e) Oger, C.; Balas, L.; Durand, T.; Galano, J.-M. Chem. Rev. 2013, 113, 1313-1350 and references herein. (f) Gieshoff, T. N.; Welther, A.; Kessler, M. T.; Prechtl, M. H. G.; von Wangelin, A. J. Chem. Commun. 2014, 50, 2261-2264. (g) Fiorio, J. L.; Goncalves, R. V.; Teixeira-Neto, E.; Ortuno, M. A.; Lopez, N.; Rossi, L. M. ACS Catal. 2018, 8, 3516-3524. (h) Reina, A.; Favier, I.; Pradel, C.; Gomez, M. Adv. Synth. Catal. 2018, 360, 3544 3552.

(6) (a) Córtese, N. A.; Heck, R. F. J. Org. Chem. 1978, 43, 39853987. (b) Shen, R.; Chen, T.; Zhao, Y.; Qiu, R.; Zhou, Y.; Yin, S.; Wang, X.; Goto, M.; Han, L. J. Am. Chem. Soc. 2011, 133, 1703717044. (c) Wang, D.; Astruc, D. Chem. Rev. 2015, 115, 6621-6686. (d) Trost, B. M.; Braslau, R. Tetrahedron Lett. 1989, 30, 4657-4660. (e) Kijama, M.; Nambu, Y.; Endo, T. Chem. Lett. 1985, 1851-1854.
(7) Examples, which use alcohols as hydrogen source. Use of isopropanol: (a) Djukic, J. P.; Parkhomenko, K.; Hijazi, A.; Chemmi, A.; Allouche, L.; Brelot, L.; Pfeffer, M.; Ricard, L.; Le Goff, X. F. J. Chem. Soc. Dalt. Trans. 2009, 2695-2711. (b) Belger, C.; Neisius, N. M.; Plietker, B. Chem. - A Eur. J. 2010, 16, 12214-12220. (c) Horn, S.; Albrecht, M.; Chem. Commun. 2011, 47, 8802-8804. (d) Kamitani, M.; Nishiguchi, Y.; Tada, R.; Itazaki, M.; Nakazawa, H. Organometallics 2014, 33, 1532-1535. (e) Payra, S.; Saha, A.; Banerjee, S. RSC Adv. 2016, 6, 52495-52499. (f) Alshakova, I. D.; Gabidullin, B.; Nikonov, G. I. ChemCatChem 2018, 10, 4874-4883. Use of glucose: (g) Manna, S.; Antonchick, A. P. ChemSusChem 2018, 12, 3094-3098. Use of ethanol: (h) Alonso, F.; Osante, I.; Yus, M. Adv. Synth. Catal. 2006, 348, 305-308. Use of methanol: (i) Tani, K.; Iseki, A.; Yamagata, T. Chem. Commun. 1999, 1821-1822. Use of ethanol for the transfer hydrogenation of ylides: (j) Reddy, A. S.; Swamy, K. C. K. Angew. Chem. Int. Ed. 2017, 129, 7088-7092.

(8) (a) Olah, G. A. Angew. Chem. Int. Ed. 2005, 44, 2636-2639. (b) Olah, G. A.; Prakash, G. K. S.; Goeppert, A. J. Am. Chem. Soc. 2011, 133, 12881-12898. (c) Olah, G. A. Angew. Chem. Int. Ed. 2013, 52, 104-107. (d) Asinger, F. Methanol- Chemie- Und Energierohstoff, Springer-Verlag, 1986.

(9) Crabtree, R. H. Chem. Rev. 2017, 117, 9228-9246.

(10) For reviews see: (a) Corma, A.; Navas, J.; Sabater, M. J. Chem. Rev. 2017, 118, 1410-1459. (b) Garbe, M.; Junge, K.; Beller, M. Eur. J. Org. Chem. 2017, 4344-4362. (c) Maji, B.; Barman, M. Synthesis 2017, 49, 3377-3393. (d) Zell, T.; Langer, R. ChemCatChem 2018, 10 , 1930-1940. (e) Sordakis, K.; Tang, C.; Vogt, L. K.; Junge, H.; Dyson, P. J.; Beller, M.; Laurenczy, G. Chem. Rev. 2018, 118, 372-433. (f) Filonenko, G. A.; van Putten, R.; Hensen, E. J. M.; Pidko, E. A. Chem. Soc. Rev. 2018, 47, 1459-1483. (g) Mukherjee, A.; Milstein, D. ACS Catal. 2018, 8, 11435-11469. (h) Gorgas, N.; Kirchner, K. Acc. Chem. Res. 2018, 51, 1558-1569. (i) Kallmeier, F.; Kempe, R. Angew. Chem. Int. Ed. 2018, 57, 46-60. (j) Reed-Berendt, B. G.; Polidano, K.; Morrill, L. C. Org. Biomol. Chem. 2018, 17, 1595-1607. (k) Vogiatzis, K. D.; Polynski, M. V.; Kirkland, J. K.; Townsend, J.; Hashemi, A.; Liu, C.; Pidko, E. A. Chem. Rev. 2019, 119, 2453-2523. (1) Irrgang, T.; Kempe, R. Chem. Rev. 2019, 119, 2524-2549. (m) Liu, W.; Ackermann, L. Manganese-Catalyzed $\mathrm{C}-\mathrm{H}$ Activation. ACS Catal. 2016, 6, 37433752. (n) H. Li, T. P. Gonçalves, D. Lupp, K.-W. Huang, ACS Catal. 2019, 9, 1619-1629

(11) (a) Elangovan, S.; Neumann, J.; Sortais, J.-B.; Junge, K.; Darcel, C.; Beller, M. Nat. Commun. 2016, 7, 12641. (b) Neumann, J.; Elangovan, S.; Spannenberg, A.; Junge, K.; Beller, M. Chem. - Eur. J. 2017, 23, 5410-5413. (c) Bruneau-Voisine, A.; Wang, D.; Dorcet, V.; Roisnel, T.; Darcel, C.; Sortais, J. B. J. Catal. 2017, 347, 57-62. (d) Andérez-Fernández, M.; Vogt, L. K.; Fischer, S.; Zhou, W.; Jiao, H.; Garbe, M.; Elangovan, S.; Junge, K.; Junge, H.; Ludwig, R. Angew. Chem. Int. Ed. 2017, 56, 559-562. (e) Mastalir, M.; Pittenauer, E.; Allmaier, G.; Kirchner, K. J. Am. Chem. Soc. 2017, 139, 8812-8815. (f) Natte, K.; Neumann, H.; Beller, M.; Jagadeesh, R. V. Angew. Chem. Int. Ed. 2017, 56, 6384-6394. (g) Chakraborty, S.; Gellrich, U.; DiskinPosner, Y.; Leitus, G.; Avram, L.; Milstein, D. Angew. Chem. Int. Ed. 2017, 56, 4229-4233. (h) Wei, Z.; de Aguirre, A.; Junge, K.; Beller, M.; Jiao, H. Catal. Sci. Technol. 2018, 8, 3649-3665. (i) Sklyaruk, J.; Borghs, J.; El-Sepelgy, O.; Rueping, M. Angew. Chem. Int. Ed. 2018, 58, 775-779. (j) Bruneau-Voisine, A.; Pallova, L.; Bastin, S.; César, V.; Sortais, J.-B. Chem. Commun. 2019, 55, 314-317.

(12) (a) Peña-López, M.; Piehl, P.; Elangovan, S.; Neumann, H.; Beller, M. Angew. Chem. Int. Ed. 2016, 55, 14967-14971. (b) Valyaev, D. A.; Lavigne, G.; Lugan, N. Coord. Chem. Rev. 2016, 308, 191-235. (c) Docherty, J. H.; Peng, J.; Dominey, A. P.; Thomas, S. P. Nat. Chem. 2017, 9, 595-600. (d) Fu, S.; Shao, Z.; Wang, Y.; Liu, Q. J. Am. Chem. Soc. 2017, 139, 11941-11948. (e) Nguyen, D. H.; Trivelli, X.; Capet F.; Paul J.-F.; Dumeignil, F.; Gauvin, R. M. ACS Catal. 2017, 7, 2022-2032. (f) Zhou, Y.; Mo, Z.; Luecke, M.; Driess, M. Chem. - Eur. J. 2017, 24, 4780-4784. (g) Brzozowska, A.; Azofra, L. M.; Zubar, V.; Atodiresei, I.; Cavallo, L.; Rueping, M.; El-sepelgy, O. ACS Catal. 2018, 8, 4103-4109. (h) Chakraborty, S.; Daw, P.; Ben David, Y.; Milstein, D. ACS Catal. 2018, 8, 10300-10305. (i) Liu, T.; Wang, L.; Wu, K.; Yu, Z. ACS Catal. 2018, 8, 7201-7207. (j) Yang, X.; Wang, C. Angew. Chem. Int. Ed. 2018, 2, 935-940. (k) Carney, J. R.; Dillon, 
B. R.; Campbell, L.; Thomas, S. P. Angew. Chem. Int. Ed. 2018, 57, 10620-10624. (l) Kulkarni, N. V.; Brennessel, W. W.; Jones, W. D. ACS Catal. 2018, 8, 997-1002. (m) El-sepelgy, O.; Matador, E.; Brzozowska, A. ChemSusChem, 2019, 12, 3099-3102. (n) Jang, Y. K.; Rueping, M.; El-sepelgy, O. Org. Lett. 2018, 20, 7779-7783. (o) Jana, A.; Reddy, C. B.; Maji, B. ACS Catal. 2018, 8, 9226-9231. (p) Liu, T.; Wang, L.; Wu, K.; Yu, Z. ACS Catal. 2018, 8, 7201-7207. (q) Barman, M. K.; Jana, A.; Maji, B. Adv. Synth. Catal. 2018, 360, 3233-3238. (r) Banerjee, D.; Kabadwal, L. M.; Das, J. Chem. Commun. 2018, 54, 14069-14072. (s) Borghs, J. C.; Zubar, V.; Azofra, L. M.; Sklyaruk, J.; Rueping, M. Org. Lett. 2020, 22, 4222-4227. (t) Zubar, V.; Borghs, J.; Rueping, M. Org. Lett. 2020, 22, 3974-3978. (u) Brzozowska, A.; Zubar, V.; Ganardi, R.-C.; Rueping, M. Org. Lett. 2020, 22, 37653769. (v) Borghs, J. C.; Tran, M. A.; Sklyaruk, J.; Rueping, M.; ElSepelgy, J. Org. Chem. 2019, 84, 7927-7935. (w) Borghs, J. C.; Azofra, L. M.; Biberger, T.; Linnenberg, O.; Cavallo, L.; Rueping, M.;
El-Sepelgy O. ChemSusChem 2019, 12, 3083-3088. (x) Matador, E.; Brzozowska, A.; El-Sepelgy, O.; Rueping M. ChemSusChem 2019, 12, 3099-3102. (y) Borghs, J. C.; Lebedev, Y.; Rueping, M.; El-Sepelgy, O. Org. Lett. 2019, 21, 70-74. (z) Garbe, M; Budweg, S.; Papa, V.; Wei, Z.; Hornke, H.; Bachmann, S.; Scalone, M.; Spannenberg, A.; Jiao, H.; Junge, K.; Beller, M. Catal. Sci. Technol., 2020, 10, 39944001.

(13) Van Putten, R.; Uslamin, E. A.; Garbe, M.; Liu, C.; Gonzalezde-Castro, A.; Lutz, M.; Junge, K.; Hensen, E. J. M.; Beller, M.; Lefort, L.; Pidko, E. A. Angew. Chem. Int. Ed. 2018, 56, 7531-7534.

(14) Chernyshev, V. M.; Astakhov, A. V.; Chikunov, I. E.; Tyurin, R. V.; Eremin, D. B.; Ranny, G. S.; Khrustalev, V. N.; Ananikov V. P. ACS Catal. 2019, 9, 2984-2995.

(15) (a) Gant, T. G. J. Med. Chem. 2014, 57, 3595-3611. (b) Atzrodt, J.; Derdau, V.; Kerr, W. J.; Reid, M. Angew. Chem. Int. Ed. 2018, 57, $1758-1784$. 